\title{
機会損失リスクを考慮した自然再生計画の評価手法 \\ Evaluation Method of Restoring Nature Plan Considering an Opportunity Loss Risk
}

\author{
安藝浩資 $^{1} \cdot$ 中野 晋 $^{2}$
}

\section{Hiroshi AKI and Susumu NAKANO}

\begin{abstract}
In this study, we discuss about an evaluation method of restoring nature planning involving a reformation of breakwater. To promote a exchange of seawater and to improve a habitat environment for coral community, reforming breakwater is examined. As an increase of permeability of a breakwater decreases an efficiency of absorbing waves, the relationships between the improvement work to promote a exchange of seawater and the disaster prevention work such as a breakwater make trade-off problem. In this paper, we examined multiple plans of reforming breakwater by considering the risk of loss about that problem. The optimum plan to remove a part of breakwater was proposed.
\end{abstract}

\section{1. はじめに}

著者らは, 四国東南部の竹ヶ島海中公園においてイシ サンゴ類の一種であるエダミドリイシ (Acropora tumida, 以下 $A t)$ を再生指標とした自然再生事業に取り組んでい る. 当海中公園は, $A t$ の群生地として 1972年に指定され た.ところが近年Atが減少し，代わって比較的濁りに強 いカワラサンゴ (Lithophyllon undulatum, 以下Lu) が増 加するなど, 優占サンゴ種に顕著な変化が生じている (中野ら, 2006).

これまでの調査から生息環境の改善には海域の海水交 換促進が不可欠であること, そのためには防波堤の改良 が有効であることを示した。 また，防波堤の改良による 環境面からの評価手法としてPHSI (Probabilistic Habitat Suitable Index） モデルを提案し, 防波堤の改良計画を $A t$ や $L u$ の生息環境の視点から評価・選定するツールとして 活用できることを報告している（安藝ら，2007，2008）.

防波堤改良にあたっての基本的な考え方は，自然環境 の側面だけでなく, 漁業・観光等の利用面や防災面もふ まえ, 総合的な見地からの改善を図ることである.した がって, 当海域の海水交換促進が, 現在の海面利用に与 える影響を極小にする必要がある。しかし，防波堤が背 後の静穏化を目的とする構造物であるため, 環境改善度 と静穏度が相反関係になり, 環境面に最適な計画が, 必 ずしも地域にとって最適な再生計画にはならない.この 関係に合意点を見いだすことは, 地域に根ざした自然再 生に向けての最重要課題であり, 環境改善に伴う利用面 への影響の定量的評価は不可欠である.

波浪の侵入を防ぐと同時に海水交換の促進を図ること を目的とした防波堤形式の研究事例は1980年代，1990年

1 正会員 博(工) ニタコンサルタント株式会社 環境部次長 2 正会員博(工) 徳島大学教授 環境防災研究センター-
代を中心に多く見られ，浮防波堤や二重半円筒ケーソン 防波堤など多くの形式が提案されている. しかし, 海水 交換の促進などの環境改善度と静穏度の相反関係に関す る問題を取り扱ったものは見受けられない.

本研究では, 海水交換促進を目的とした防波堤改良に よる海域の自然再生計画について, Atの生息環境を指標 とした環境改善度と, 静穏度の低下による海面利用度の 低下という相反関係を, 再生計画による機会損失リスク を考慮することから評価する.

\section{2. 防波堤周辺海域の特性}

対象とする防波堤は, $3.2 \mathrm{t}$ 型の消波ブロックを水平 2 層 積みにした延長 $112 \mathrm{~m}$ のものである。図-1に示すように 激浪方向に対し, 竹ヶ島の背後に位置していることから, 主に竹ヶ島を迂回した回折波が対象となる.

周辺の波浪状況を把握するため, 水圧検知式波高計 (ALEC 社：COMPACT-WH）を用いて, 波浪観測（偶数 正時毎, サンプリング $0.5 \mathrm{~s}, 10$ 分観測）を行った。波浪 観測地点は図-2に示す防波堤の背面（Tk）および防波堤 の前面（WA）と竹ヶ島の南側海域（W4）の3点である. 入射方向に対してW4の前面には波浪を遮るものは存在 しない. 観測期間は，2006年7月 1日〜2006年8月 12 日

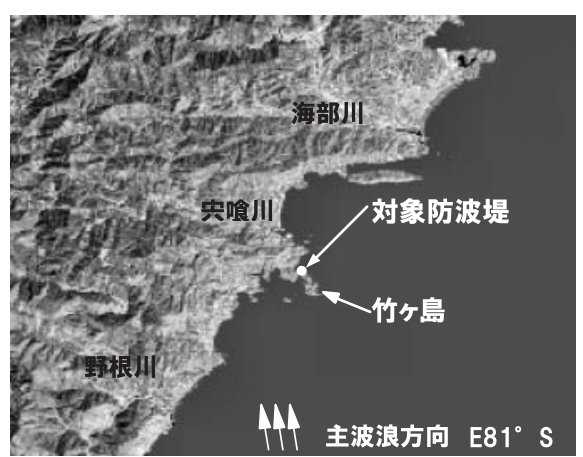

図-1 激浪方向と対象防波堤の位置関係 


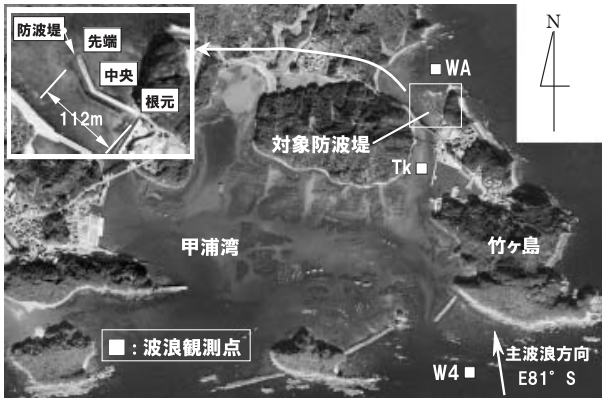

図-2 対象防波堤と波浪観測地点

である。

図-3はWAに対するTkの有義波高比 (24時間移動平均), およびW4に対するWAのそれを示したものである.

図中の 4 桁の数字は 2006 年度の台風番号を意味する. 図よりWAではW4の $25 \%$ ～60\%程度の波高であること， また，堤背面のTkではWAの $10 \%$ 30\%程度であること がわかる。これは，上記した回折効果に加えて，堤前面 部では DL $\pm 0.0 \mathrm{~m}$ 以浅の地形が大半を占めており，天然 のリーフ状地形を呈していることや，沖合に突堤状地形 を呈するDL-1.0m 以浅の磯が存在しており，これらの位 置・地形特性により，竹ヶ島により回折された波浪が, 堤前面の突堤状地形およびリーフ状地形により砕波さ れ，堤直近部では大きく減衰するためである.

\section{3. 改良計画と生息環境面からの評価}

図-4は，表-1に示す6ケースの改良計画を例に挙げ， これらを行った場合に生じる環境改善効果を，Atの生息 可能区画数を指標として式（1）で表したものである. 図中には改良対象の防波堤を完全に撤去した場合に相当 する1990年のものと，現在の状態である 2003 年時のも のも参考として併記した.

$$
\text { 環境改善度 }(\%)=\frac{A t \text { (計画 })-A t(2003)}{A t(1990)-A t(2003)} \times 100 \quad \cdots(1)
$$

ここに，式中の $A t$ は $A t$ の生息可能区画数であり，PHSI 值 0.365 以上の区画である. 括弧内の数字は，基準年で ある 1990年時と 2003 年時を意味する。評価対象は 3335 区画である。
表-1 改良計画の検討ケース

\begin{tabular}{c|c}
\hline 計 画 & \multicolumn{1}{c}{ 概 要 } \\
\hline TM60 & 先端部 $60 \mathrm{~m}$ を撤去 \\
\hline CM60 & 中央部 $60 \mathrm{~m}$ を撤去 \\
\hline BM60 & 根元部 $60 \mathrm{~m}$ を撤去 \\
\hline TM80 & 先端部 $80 \mathrm{~m}$ を撤去 \\
\hline CM80 & 中央部 $80 \mathrm{~m}$ を撤去 \\
\hline BM80 & 根元部 $80 \mathrm{~m}$ を撤去 \\
\hline
\end{tabular}

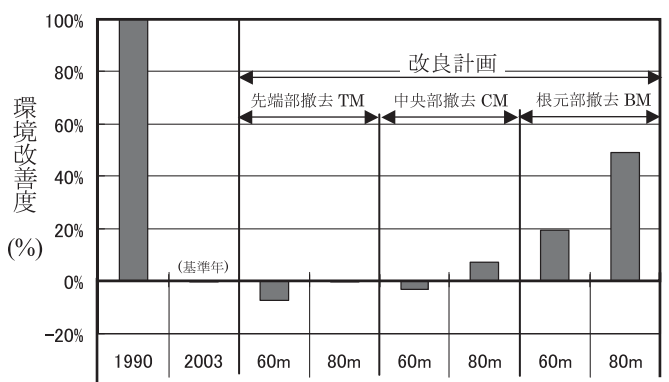

図-4 各改良計画による環境改善度

改良による環境改善度の違いを見るため，先端部，中 央部，および根元部の $60 \mathrm{~m}$ 撤去案（TM60，CM60， BM60)，80m 撤去案（TM80，CM80，BM80）を比較す ると，いずれも根元部の改良案の効果が高いことがわか

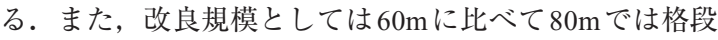
に改良効果が増加していることがわかる.

\section{4. 改良計画の利用面からの評価}

\section{（1）リスクシナリオの設定}

自然再生では，自然環境の再生に主眼をおいた事業や 活動を，その周辺地域に潜在する各種リスクへの影響を 考慮しつつ推進する必要がある．しかし，すべてのリス クを同時に対象とすることは困難である，そのため，対 処しなければならないリスクと，そのリスク増減を明確 にする必要がある．防波堤の改良時には，周辺海域での 静穏度の変化が予想される漁船の航行日数の低下などが 予想される。ここでは，自然災害リスクのうち，漁業や 観光等の利用面から航行可能日数の低下を機会損失リス クとして特定し，次の3つのリスクシナリオを設定した.

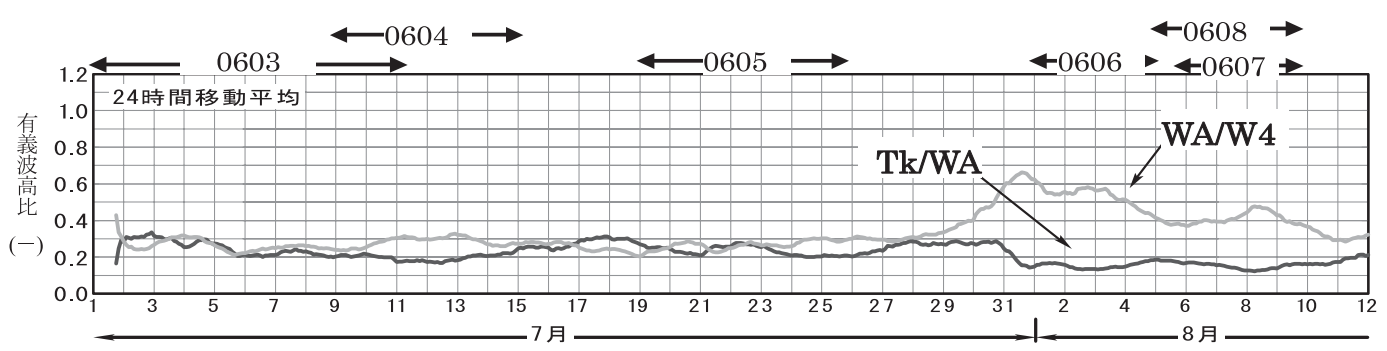

図-3 有義波高比(2006年7月 1 日～2006年 8 月 12 日) 


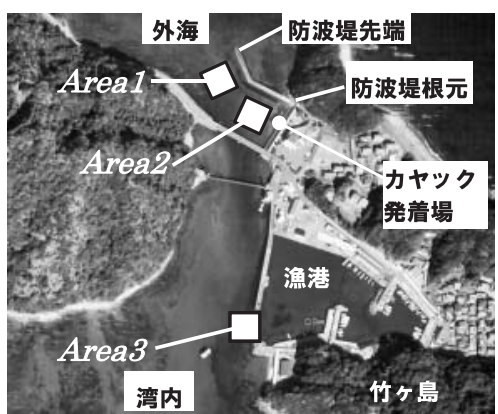

図-5 評価対象領域

それぞれに対して，防波堤改良による環境改善効果と図5 に示す評価海域での機会損失リスクを評価することに より，適切な改良形式について検討した。

〔リスクシナリオ1〕：防波堤の背面海域は，漁船の航 路として利用されている。 そのため, 防波堤を改良する ことにより，漁船船舶の航行に支障が生じる（Area1）.

〔リスクシナリオ 2〕：防波堤の根元部分の背面付近は, カヤック発着場, 陸揚げ場として利用されている. カヤ ックの運行基準についての関係者からの聞き取りでは, 現時点で, 運行するか否かは, 風や潮時（上げ潮か下げ 潮か) などを勘案し, 指導員が判断している. しかし, 防波堤の改良により堤背面の静穏度が低下することで, 波浪により陸揚げ準備ができなくなる等, 波浪が支配要 因になり海面利用に支障が出る可能性がある (Area2).

〔リスクシナリオ 3]：竹ヶ島漁港口の静穏度低下に伴 い，漁港内での陸揚げ準備作業に支障が出るなど利便性 が低下する (Area3).

\section{（2）機会損失リスクの評価概念}

概念図を図-6に示す。機会損失リスクを，波高限界值 の年間超過日数の変化割合で評価した。このとき波高限 界值には, 漁港の水域施設の計画時に用いられる施設の 使用可能な波高限界を示す標準值を用いた．対象海域の 水深は概ね $3.0 \mathrm{~m}$ 未満であることから, シナリオ 1 に対し て航路としての使用限界とされる $0.9 \mathrm{~m}$ を, シナリオ 2,3 に対しては， $0.3 \mathrm{~m}$ を適用した。

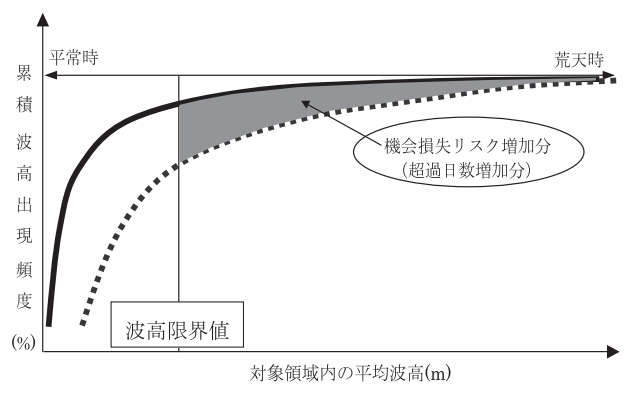

図-6 機会損失リスクの概念図

\section{（3）累積波高出現頻度の算定}

機会損失リスクを評価するにあたっては，通年での静 穏度の変化が重要である。そのため, 佐喜浜観測所（高 知県室戸市佐喜浜町）で観測された波高出現確率分布 （1977-2000）を用いて，改良形式毎の防波堤周辺及び背 後での平均波高の出現頻度を算定した。検討対象波向は $\mathrm{SSE}-15^{\circ}$ である. 波高階級 $0 \mathrm{~m} \sim 7 \mathrm{~m}$ の波高出現頻度を 図-7に示す。

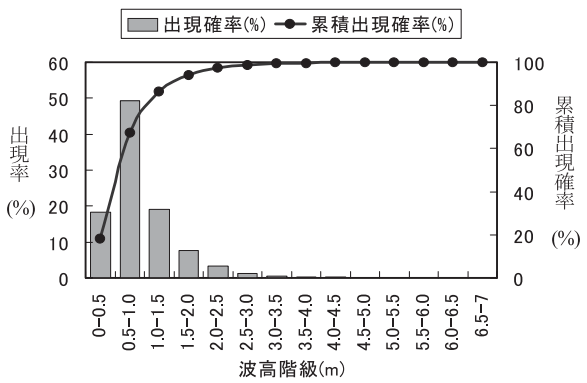

図-7 波高出現頻度（佐喜浜観測所 1977-2000）

(4) 防波堤改良による機会損失日数の変化

表-1に示した改良ケースに対して，エネルギー平衡方 程式による平面波浪変形解析により, 対象海域の静穏度 変化の求めた. 解析は表-2 に示す 8 段階である. 防波堤 改良の影響が生じるArea1 と Area2について累積波高出現 頻度を算定し, 最小二乗近似を行うことから波高限界值 を超える波高が出現する日数（年間出現波高超過日数）

表-2 解析ケース

\begin{tabular}{c|c|c|c|c}
\hline & $\begin{array}{c}\text { 入射波高 } \\
(\mathrm{m})\end{array}$ & $\begin{array}{c}\text { 周期 } \\
(\mathrm{s})\end{array}$ & $\begin{array}{c}\text { 出現確率 } \\
(\%)\end{array}$ & $\begin{array}{c}\text { 累積出現確率 } \\
(\%)\end{array}$ \\
\hline 1 & 0.25 & 9.3 & 18.2 & 18.2 \\
\hline 2 & 0.75 & 8.5 & 49.2 & 67.4 \\
\hline 3 & 1.25 & 9.2 & 19.2 & 86.6 \\
\hline 4 & 1.75 & 10.1 & 7.7 & 94.3 \\
\hline 5 & 2.25 & 10.6 & 3.3 & 97.5 \\
\hline 7 & 2.75 & 11.0 & 1.3 & 98.8 \\
\hline 8 & 3.25 & 11.6 & 0.6 & 99.4 \\
\hline
\end{tabular}

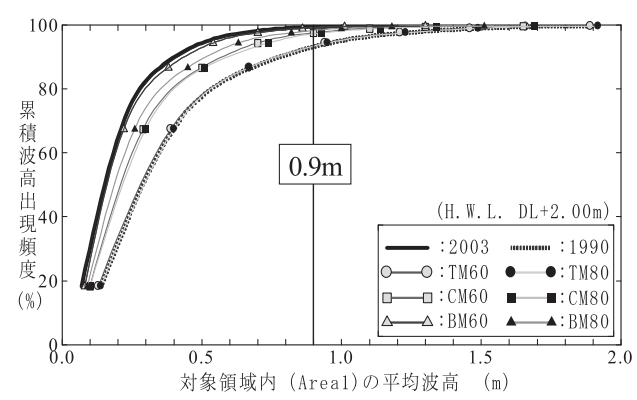

図-8 累積波高出現頻度曲線（Area1） 


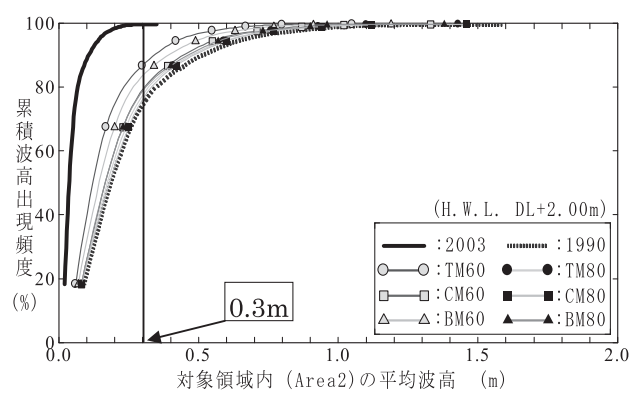

図-9＼cjkstart累積波高出現頻度曲線（Area2）

を求めた. 累積波高出現頻度曲線を図-8 と図-9に示した.

\section{a) 機会損失日数 [Area1]}

図-10 はシナリオ 1 に対応する波高限界值 $0.9 \mathrm{~m}$ の場合の 超過日数を比較したものである. 1990年には波高 $0.9 \mathrm{~m}$ を 超過する日数は年間 25 日であったのが，防波堤ができる ことにより2003年には3日に激減しており，当防波堤の 波浪抑制効果が伺える. 改良形式毎の影響を見ると先端 部を撤去するTM60，TM80では1990年とほぼ同じとな る.一方, BM60では現状からほとんど変化はなく, 改 良の影響は極めて少ない.

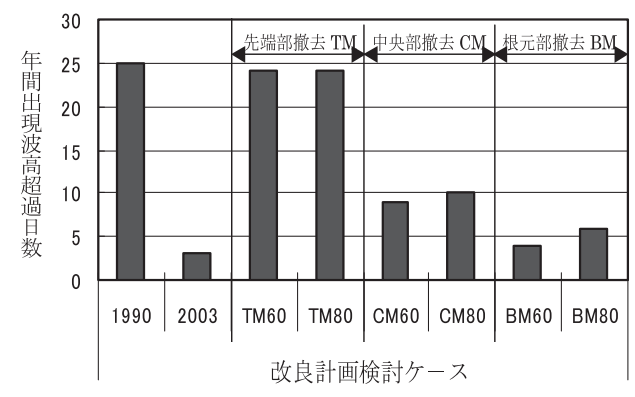

図-10 各ケースの年間出現波高超過日数（Area1）

\section{b) 機会損失日数 [Area2]}

図-11 はシナリオ 2 に対応する波高限界值 $0.3 \mathrm{~m}$ の場合の 超過日数を比較したものである. 1990 年には波高 $0.3 \mathrm{~m}$ を 超過する日数は年間 98 日であったが，防波堤ができるこ とにより2003年には2日に激減しており，当Areaの静穏 度向上にも防波堤の効果が伺える。また，図より中央部 を撤去した場合（CM60，CM80）の影響が最も大きく， 比較的影響が軽微と考えられた先端部撤去（TM60, TM80）の場合でも，大幅に超過日数が増加しているこ とがわかる．根元部を撤去した場合が最も影響が小さい が，その場合でも超過日数は，BM60の場合で現状の 2 日 から63日に，BM80の場合で2日から82日と大幅に増加 する。なお，Area1で $0.9 \mathrm{~m}$ 以下であるにもかかわらず， Area2で $0.9 \mathrm{~m}$ 以上となり航路として使用できない場合が 生じる可能性についても別途検討しているが， $0.9 \mathrm{~m}$ 超
過する日数をArea1 とArea2で比較するといずれの計画に おいても，Area1の超過日数が多いため，Area2の波高 は航路としての使用条件を支配しないことを確認して いる.

\section{c）機会損失日数 [Area3］}

Area3については，表-2に基づき算定した波高が全て $0.05 \mathrm{~m}$ 以下であった。そのため当Area まで影響が及ばな いと判断した.

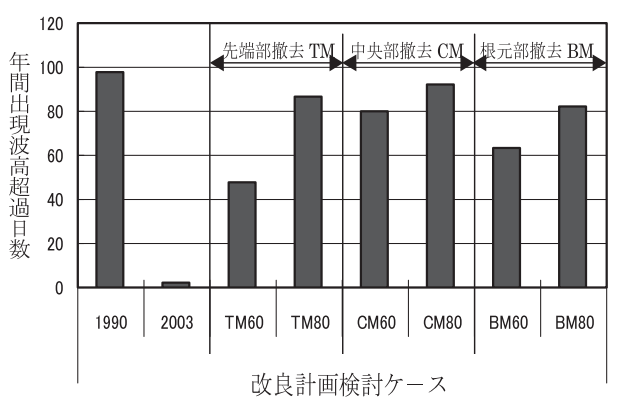

図-11 各ケースの年間出現波高超過日数（Area2）

\section{（4）防波堤改良による機会損失日数の变化}

各改良形式による海面利用度と環境改善度の变化を下 図に示した，図-12 はシナリオ1に，図-13 はシナリオ 2 に 対応する，海面利用度は，防波堤設置前の1990年と現在 （2003年）の日数変化分に対する計画実施時の相対的な 変化度であり，2003年が $100 \%$ となる。同様に環境改善 度はPHSIモデルで評価された $A t$ 生息可能区画数の，現 在と計画時の割合であり，図-4に対応する．図中の破線 は，環境改善度に伴い，海面利用度が低下する比率を示 している。なお，海面利用度は次式（2）より算定した。

海面利用度 $(\%)=\frac{\text { 超過日数 }(1990) \text {-超過日数(計画 })}{\text { 日数 }(1990) \text {-超過日数 }(2003)} \times 100 \cdots(2)$

図-12より，最大の環境改善度が期待できる計画は BM80である. また，改善度の増加というべネフィット に対して，利用度低下というデメリットが増加する割合 が少ないのはBM60 と BM80である。それら以外は全て メリットに比べてデメリットの増加割合が大きいことが わかる.

図-13に示すシナリオ 2 に対しては，BM60に比べ, BM80ではメリットに対するデメリットの増加割合が少 ない。したがって，環境改善度と海面利用度の両面を考 慮すると BM80が優位となる。しかし，BM80では海面 利用度が $83 \%$ 程度低下し，BM60より 20 ポイントほど低 下割合が多い。

本自然再生計画では極力現状の海面利用度を低下させ

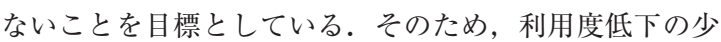
ないBM60を当面の第1案とし，順応的な考えの下，モ 


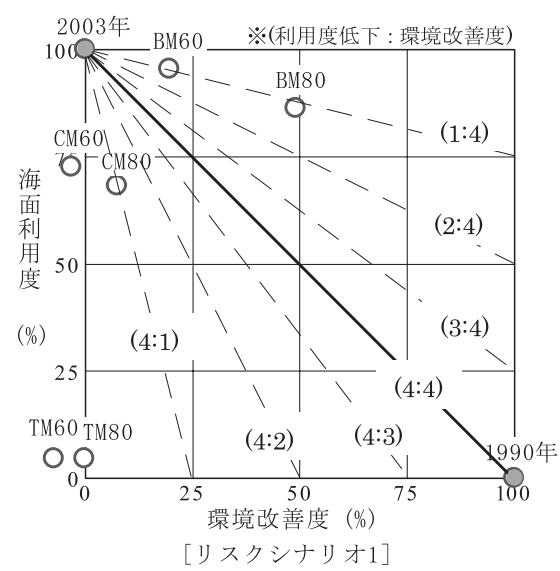

図-12 海面利用度と環境改善度

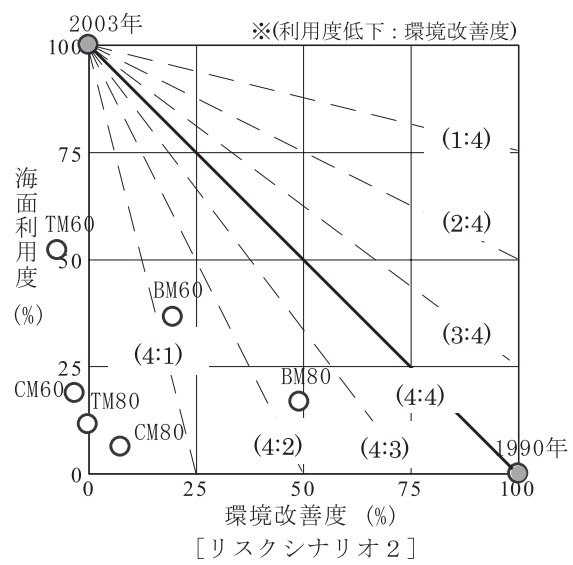

図-13＼cjkstart海面利用度と環境改善度

ニタリングを行いつつ, より高い環境改善効果が得られ る BM80の実施可能性について地元関係者との合意形成 を図ることを最適案とした。

\section{5. おわりに}

本論文では，海水交換促進を目的とした防波堤の改良 において，改良コストが概ね同等な6ケースを例に挙げ 機会損失リスクを考慮することから，相反関係となる環 境改善度の向上と海面利用度の低下の両面から評価した 事例を報告した。

以下に本研究で得られた主要な知見を記す。
(1) 6つの改良計画それぞれについて，PHSIモデルにより 環境改善度を評価した。その結果，当初考えられてい た先端部や中央部の撤去と比較して, 根元部の改善効 果が高いことがわかった。

(2) 現地波浪観測から，防波堤前面のWAでは外海域の W4の 25\%〜 60\%の波高であること，また，堤背面の TkではWAの 10\%〜30\%程度であることがわかった.

(3) 航行可能日数の低下を機会損失リスクとして特定し, 3つのリスクシナリオに対する海面利用度の変化から 6 案の再生計画を評価した。ささに, 環境改善度を勘案 することから, BM60 と BM80の優位性を示すととも に, 本自然再生計画の目標を踏まえ, より利用度低下 の少ないBM60を第1案とした。ただし，最終的には ここでの評価結果を踏まえて, 地元関係者と十分な協 議を行って決定するとともに, 実施後もモニタリング を行いつつ，順応的に対応する必要がある。

自然再生では住民合意の形成や，参画住民との目標意 識の共有を図ることが大切である，そのためには，環境 面だけでなく防災面や利用面も含めた総合的な視点に立 つことが重要である．自然再生計画を評価する上では, 計画によって現状から変化する様々なリスクについて対 処する必要がある. しかし, 全てのリスクを現状に保つ ことが難しく, 対処策として保有, 移転, 軽減, 回避の いずれを取るかなど, 今後, 再生計画へのリスクマネジ メント的手法の導入は不可欠である.

謝辞：本論文は, 竹ヶ島海中公園自然再生事業の一環と して行った検討結果をとりまとめたものである.それら に関わった, 協議会・専門委員会や事務局の方々に謝意 を表する。

\section{参 考 文 献}

安藝浩資・中野 晋・盛 治夫（2008）：PHSIモデルによる サンゴの生息環境評価と自然再生計画の策定, 海岸工学 論文集，第 55 巻, pp. 1116-1120.

安藝浩資. 中野晋・内田紘臣・岩瀬文人・御前 洋 （2007）：沿岸域の自然再生計画における順応的管理への HSI モデルの適用性，海洋開発論文集，第 23 巻, pp. 501506.

運輸省港湾局（1994）：新形式防波堤技術マニュアル，240p.

（社）全国漁港漁場協会（2003）：漁港・漁場の施設の設計の 手引き, p. 529.

中野 晋·安藝浩資 - 内田紘臣 - 岩瀬文人 · 川口 始 - 吉崎 仁美（2006）：サンゴを対象とした自然再生事業におけ る普及啓発活動とその効果, 海洋開発論文集, 第 22 巻, pp. 63-68. 